\title{
Development of a More Effective Hearing Screening Questionnaire for Infants and Children during Medical Check-Ups
}

\author{
Jiyoung Lee ${ }^{1}$, Jihye Rhee ${ }^{1}$, Su-Kyoung Park ${ }^{2}$, Jiwon Chang ${ }^{2}$, Jin-Sook Kim ${ }^{3}$, Kyoung Ho Park ${ }^{4}$, \\ Hyong Ho Cho ${ }^{5}$, Jun Ho Lee ${ }^{1}$, Son Moon Shin ${ }^{6}$, and Moo Kyun Park ${ }^{1}$ \\ ${ }^{1}$ Department of Otorhinolaryngology-Head and Neck Surgery, Seoul National University Hospital, \\ Seoul National University College of Medicine, Seoul; and ${ }^{2}$ Department of Otorhinolaryngology-Head and Neck Surgery, \\ Hallym University College of Medicine, Seoul; and ${ }^{3}$ Department of Audiology, Hallym University, Chuncheon; and \\ ${ }^{4}$ Department of Otolaryngology-Head and Neck Surgery, College of Medicine, The Catholic University of Korea, Seoul; and \\ ${ }^{5}$ Department of Otolaryngology-Head and Neck Surgery, Chonnam National University Medical School, Gwangju; and \\ ${ }^{6}$ Department of Pediatrics, Cheil Hospital, Seoul, Korea
}

\section{영유아 건강검진용 청각문진 개발}

이지영 ${ }^{1} \cdot$ 이지혜 ${ }^{1} \cdot$ 박수경 $^{2} \cdot$ 장지원 ${ }^{2} \cdot$ 김진숙 $^{3} \cdot$ 박경호 $^{4} \cdot$ 조형호 $^{5} \cdot$ 이준호 $^{1} \cdot$ 신손문 $^{6} \cdot$ 박무균 $^{1}$ 서울대학교 의과대학 서울대학교병원 이비인후과학교실, ${ }^{1}$ 한림대학교 의과대학 이비인후과학교실, ${ }^{2}$ 한림대학교 청각학과, ${ }^{3}$ 가톨릭대학교 의과대학 이비인후과학교실, ${ }^{4}$ 전남대학교 의과대학 이비인후과학교실, ${ }^{5}$ 제일병원 소아과 ${ }^{6}$

\author{
Received August 7,2015 \\ Revised December 4, 2015 \\ Accepted December 5, 2015 \\ Address for correspondence \\ Moo Kyun Park, MD, PhD \\ Department of Otorhinolaryngology- \\ Head and Neck Surgery, \\ Seoul National University Hospital, \\ Seoul National University \\ College of Medicine, 101 Daehak-ro, \\ Jongno-gu, Seoul 03080, Korea \\ Tel $+82-2-2072-2448$ \\ Fax $+82-2-745-2387$ \\ E-mail aseptic@snu.ac.kr
}

Background and Objectives To improve hearing screening, we developed a more effective hearing screening questionnaire for infants and children to be utilized during medical check-ups. Subjects and Method Through literature review and discussions with an advisory council, we selected 10 questions to ask parents at each of the seven screening periods for their infants and children. In total, 223 parents of infants and children with and without hearing impairment (119 normal hearing, 104 hearing impaired) answered questionnaires at seven university hospitals in Korea. The advisory council modified questions with regard to sensitivity, specificity, positive, and negative prediction rate, preventing duplication among screening periods, and to address other questions related to development.

Results For hearing screens, we asked five questions per screening period. Collectively, these questions had $40-100 \%$ sensitivity and $45-90 \%$ specificity at each of the seven screening periods. Conclusion Although we do not advise that hearing questionnaires replace hearing tests, we developed in this study a more effective questionnaire that we suggest could be utilized during medical check-ups to enhance the hearing screening process.

Korean J Otorhinolaryngol-Head Neck Surg 2016;59(4):273-80

Key Words Children $\cdot$ Hearing $\cdot$ Infant $\cdot$ Questionnaire $\cdot$ Screening.

\section{서 론}

유소아(childhood) 난청의 원인은 발병 시기에 따라 선천 성 난청과 지연성 난청으로 구별할 수 있다. 국내의 경우 선 천성 난청은 신생아 난청 선별검사를 통해 진단이 되고 있으 며 현재 전체 신생아에 대한 난청 선별검사를 추진 중이다.
외국 연구에 의하면 어린이 난청이 천 명당 3.47 인 경우, 천 명당 1.89 명은 지연성 난청이며 난청 고위험군에서 좀 더 지 연성 난청의 발생이 높기는 하나 발생 환아의 절반은 정상 아이이기 때문에 난청 고위험군 아이뿐만 아니라 모든 아이 에 대해 학령기(school age)가 되기 전까지 체계적인 난청 진 단 프로그램이 필요하다고 한다. ${ }^{1,2)}$ 우리나라의 경우에도 
2011년 장애인 실태조사 결과 돌(1세) 이전에 난청이 발생한 것으로 파악된 경우가 $2.7 \%$ 이며 돌 이후 발생한 난청 중 $7.9 \%$ 가 1 4세 사이에 발생한 것으로 조사되어 영유아(infants and toddlers) 난청의 발생 비율이 신생아 난청에 비해 오히 려 많은 것을 알 수 있다. 하지만 유소아 난청의 절반을 차지 하는 지연성 난청의 경우에는 적절한 선별검사가 이루어지지 않았고 선별검사의 필요성이 보호자들에게 잘 알려져 있지 못하였다. ${ }^{3)}$

현재 우리나라의 청각 부분의 검진은 신생아기(신생아청각 선별검사, $200 \%$ 저소득층 대상, 보건복지부), 영유아기(청각 문진 7회, 영유아 검진, 보건복지부), 학생(청각문진과 1개 주 파수 검사, 초 1, 초4, 중1, 고1, 교육부), 생애전환기(순음청력 검사, 40,66 세, 보건복지부)에서 시행되고 있으며 기존 영유 아 건강검진은 2007 년에 시작되어 4개월, 9 개월, 18 개월, 30 개월, 4세, 5세, 6세 시기(총 7시기)에 걸쳐 시행되고 있다. 청 각문진은 시기별 5 문항으로 구성되어 있으며, 1 개의 문항이 라도 이상 소견을 보일 때에는 이비인후과 전문병원으로 의 뢰하고 있다. 학령전기(preschool)에 순음청력검사를 의무적 으로 시행하는 영국, 일본, 독일 등과 비교하여 각 시기별 5 개의 문진을 통해 목표질환인 난청을 발견하는 것은 근본적 으로 한계를 가지고 있다. 2012년에 실시한 청각문진사유별 유소견율은 문항별로 큰 차이가 있었다. 또한 건강검진자료 에서 청각 진단코드로 문진항목의 민감도와 특이도를 측정 하려 하였으나, 실제 입력된 청각진단코드가 실제 난청을 의 미하는지 여부를 확인할 수 없어 그 문진의 유용성을 측정 하는 데 한계가 있었다. 하지만 현행 영유아 건강검진의 예산 상 순음청력검사를 시행하지 못하고 있고 기존 청각문진은 문진별 민감도 및 특이도 분석이 이루어진 적이 없어 차선책 으로 청각문진이 얼마나 난청아를 선별가능한지에 대해 분 석하여 국가검진에서 사용되는 적절한 청각문진 항목을 제 시하고자 하였다.

이에 새로운 영유아 검진의 청각문진에 대한 검증 연구가 필요하여 실제 난청으로 진단받은 유소아와 청력이 정상인 유소아를 대상으로 청각문진을 시행하고 각 청각 문진 항목 이 난청을 선별하기 위해 적합한 문항인지를 민감도, 특이도, 양성 예측률, 음성예측률을 측정하여 분석하였다. 문진항목 을 재정비하여 유소아 보호자들이 불필요한 걱정을 하지 않 고 필요한 경우 의료기관에서 청력검사를 시행하도록 하고 자 하였다. 영유아용 청각선별 문항을 개정하기에 앞서 청각 학 교수님의 자문과 문헌조사를 통해 선별된 문항에 대한 다 기관 전향적 설문 연구를 기획하였다. 이를 통해 새로운 영 유아 난청 선별용 문진을 개발하고자 하였다.

\section{대상 및 방법}

\section{문헌 검색 및 후보 문항선정}

유소아 난청의 선별에 적합할 것으로 보이는 문항을 시기 별 10 개씩 문헌 조사를 통하여 선별하였다. ${ }^{4-16}$ 7시기는 영유 아 건강검진 시기인 4 개월, 9 개월, 18 개월, 30 개월, 4 세, 5 세, 6 세를 기준으로 하였고 문항 선별은 청각학 교수 의해 추천을 받았다. ${ }^{12-16}$

\section{연구 대상}

대상아가 최근 6개월 이내 시행한 순음청력검사, 유희청력 검사 혹은 뇌간유발반응검사소견을 참고로 정상아와 난청 환아를 구분하였다. 영유아의 특성상 1 개월 이내 청력검사 를 시행한 경우가 많지 않아 6개월 이내 소견을 참고하였으 며 설문시 특별한 청력이상이 없는 경우를 대상으로 하였다. 청력검사상 순음청력검사가 가능한 경우 정상아는 양측 청 력이 $25 \mathrm{~dB} \mathrm{HL}$ 이하인 경우로 난청 환아는 양측 청력이 40 $\mathrm{dB} \mathrm{HL}$ 이상인 경우로 정의하였다. 청력은 $500,1000,2000$, $4000 \mathrm{~Hz}$ 를 이용한 4분법을 기준으로 하였고 혹은 검사 가능 한 주파수의 평균을 사용하였다. 단, 일측성 난청(unilateral hearing loss)은 본 연구에서 제외하였다. 순음청력검사가 불 가능한 경우는 Click ABR 또는 frequency-specific ABR을 사용하여 정상아는 양측 뇌간유발반응검사역치가 $35 \mathrm{~dB}$ $\mathrm{nHL}$ 이하인 경우로, 난청 환아는 양측 뇌간유발반응검사역 치가 $40 \mathrm{~dB} \mathrm{nHL}$ 이상인 경우로 정의하였다. 대상아의 청력 검사 소견이 없는 경우, 이과적 검진상 이상소견이 있는 경 우, 난청 외 인지장애, 지능장애, 발성장애 등을 동반한 경우, 시각장애, 발달장애를 동반한 경우, 부모의 모국어가 한국어 가 아닌 경우는 제외하였다(Table 1).

설문지에 대한 민감도 및 특이도 조사 연구로 특별히 목표 수를 산정하지는 않으나, 최소 모수 분석에 필요한 각 군 30 명 이상을 모집하기로 하였으며, 따라서 탈락률 $10 \%$ 를 고려 하여 총 7 개의 군에 각군 34 명을 모집하여(정상군, 환자군

Table 1. Age distribution of the enrolled children in the study

\begin{tabular}{cccc}
\hline $\begin{array}{c}\text { Age } \\
\text { (months) }\end{array}$ & $\begin{array}{c}\text { Normal } \\
\text { group (cases) }\end{array}$ & $\begin{array}{c}\text { Hearing loss } \\
\text { group (cases) }\end{array}$ & $\begin{array}{c}\text { Total } \\
\text { (cases) }\end{array}$ \\
\hline $4-5$ & 21 & 23 & 44 \\
$9-12$ & 11 & 22 & 33 \\
$18-24$ & 15 & 15 & 30 \\
$30-36$ & 22 & 24 & 46 \\
$42-48$ & 20 & 11 & 31 \\
$54-60$ & 15 & 6 & 21 \\
$66-71$ & 15 & 3 & 18 \\
\hline Total & 119 & 104 & 223 \\
\hline
\end{tabular}


$1: 1$ 배정) 총 238명을 모집하려고 하였다. 대상아의 보호자에 게 병원 방문 시 동의서 설명 후 청각문항지를 나누어주거나 의사의 문진으로 작성하였다. 본 연구는 서울대학교 병원을 비롯한 소속 기관의 Institutional Review Board 승인을 받 았다.

\section{설문조사}

2014년 3월 1일부터 2014년 8월 4일까지 설문이 진행되었 다. 전국의 7 개 대학병원(서울대학교병원, 분당서울대학교병 원, 한림대학교 성심병원, 서울아산병원, 순천향대학교 천안 병원, 동아대학교병원, 전남대학교병원)을 방문하여 6개월 이 내에 객관적 청력검사를 받은 총 223 명의 정상아 및 양측 40 $\mathrm{dB}$ 이상의 난청 환아(정상군 119 명, 난청군 104 명)의 보호자 가 참여하였다. 보호자는 대상아의 상태를 잘 이해하고 있는 보호자에 한하여 선정하였다. 시기는 설문 조사일을 기준으 로 4개월 0일 6개월, 9개월 0일 12개월, 18 개월 0일 24개 월, 30 개월 0일 36개월, 42개월 0일 48개월, 54개월 0일 60 개월, 66 개월 0 일 71 개월이었다.

\section{문항선정 및 자문단회의}

청각문항의 민감도, 특이도, 양성예측률, 음성예측률을 측 정하여 통계적으로 민감도와 특이도가 높은 문진항목을 새 로운 청각문진 항목으로 선택하였다.

전문가 자문과 인지발달과의 상관관계를 고려하여 최종 5 문항을 선정하였으며 자문위원단 회의를 통하여 분석된 문
항에 대한 발달선별검사와의 중복여부 점검, 연령별 중복문 항과 문항별 이해도를 높이기 위한 용어 및 단어 선정, 전체 유소아 선별검사 설문지와의 통일성 등을 고려하여 문항들을 개정하였다. 자문단에는 청각학 교수 1 명, 이과학 교수 4명, 소아과 교수 2 명이 참석하였다.

\section{결 과}

4개월 0일 6개월 군에서 문항별 민감도와 특이도, 양성예 측률과 음성예측률은 Table 2와 같았다. 이 중 양성예측률이 높았던 상위 5 개 문항의 조합은 난청의 진단에 있어, 민감도, 특이도, 양성예측률과 음성예측률이 각각 $100.0 \%, 38.1 \%$, $63.9 \%, 100.0 \%$ 로 나타났다.

9개월 0일 12 개월 군에서 양성예측률이 높았던 5 개 문항 의 조합을 통한 난청의 유소견률은 Table 3과 같았다. 같은 원리로 18 개월 0일 24개월 군, 30 개월 0일 36개월 군 42개 월 0일 48개월 군, 54개월 0일 60개월 군, 그리고 66개월 0 일 71개월 군에서 상위 5 개 문항을 각각 양성예측률이 높은 순으로 배열하였다. 이들 5 개 문항의 조합을 통해 한 문항이 라도 양성 반응시 난청을 의심할 수 있는 경우로 가정하는 경우 난청의 선별의 민감도는 100 40\%, 특이도 100 38.1\% 양성예측률 100 50\%, 음성예측률 100 45.5\%로 매우 다양 한 폭을 가지게 나타났다(Table 4-8).

자문회의를 통해 중복성 및 용어 수정 후 각 군에서 최종 적으로 채택된 5 개의 문항은 Table 9와 같았다.

Table 2. Analysis of the questions for the infants aged 4-6 months

\begin{tabular}{|c|c|c|c|c|}
\hline Items & $\begin{array}{l}\text { Sensitivity } \\
(\%)\end{array}$ & $\begin{array}{l}\text { Specificity } \\
(\%)\end{array}$ & $\begin{array}{l}\text { Positive predictive } \\
\text { value (\%) }\end{array}$ & $\begin{array}{l}\text { Negative predictive } \\
\text { value }(\%)\end{array}$ \\
\hline $\begin{array}{l}\text { 1. 큰 소리에 잠에서 깨거나, 놀라거나, } \\
\text { 표정 변화 등으로 반응합니까? }\end{array}$ & 13.0 & 100.0 & 100.0 & 51.2 \\
\hline $\begin{array}{l}\text { 2. 익숙한 목소리를 들으면 조용해지거나 동작을 } \\
\text { 멈추고 듣는 것처럼 보입니까? }\end{array}$ & 4.3 & 100.0 & 100.0 & 47.6 \\
\hline $\begin{array}{l}\text { 3. 위의 문항이 '예'인 경우 청력검사 결과가 } \\
\text { 양호(양측 통과 또는 이상 없음)라고 하였습니까? }\end{array}$ & 87.0 & 95.8 & 95.4 & 82.4 \\
\hline $\begin{array}{l}\text { 4. 다양한 소리(끽끽거림, 껄껄거림, 높은 비명소리 등)를 } \\
\text { 낼 수 있습니까? }\end{array}$ & 21.7 & 90.0 & 71.4 & 50.0 \\
\hline $\begin{array}{l}\text { 5. 출생 후 신생아 집중치료실(중환아실)에 } \\
\text { 5일 이상 입원한 적이 있습니까? }\end{array}$ & 52.2 & 73.7 & 80.0 & 82.4 \\
\hline 보호자가 말을 하면 미소 지을 수 있습니까? & 4.3 & 66.7 & 63.2 & 56.0 \\
\hline $\begin{array}{c}\text { 소리가 나는 쪽으로 미숙하지만 고개를 돌리거나 } \\
\text { 몸의 방향을 바꾸기도 하는 반응을 보입니까? }\end{array}$ & 8.7 & 90.5 & 50.0 & 46.3 \\
\hline 깔깔거리며 웃을 수 있습니까? & 8.7 & 80.0 & 50.0 & 47.5 \\
\hline 소리 나는 장난감(예를 들어 딸랑이 등)을 좋아합니까? & 13.0 & 71.4 & 33.3 & 42.9 \\
\hline 옹알이, '아', ‘오' 등의 소리를 냅니까? & 0.0 & 95.2 & 0.0 & 46.5 \\
\hline 신생아기에 청각선별검사(청력검사)를 실시하였습니까? & 0.0 & 90.5 & 0.0 & 45.2 \\
\hline 5개 문항의 조합 & 100.0 & 38.1 & 63.9 & 100.0 \\
\hline
\end{tabular}


Table 3. Analysis of the questions for the infants aged 9-12 months

\begin{tabular}{|c|c|c|c|c|}
\hline Items & $\begin{array}{l}\text { Sensitivity } \\
(\%)\end{array}$ & $\begin{array}{l}\text { Specificity } \\
(\%)\end{array}$ & $\begin{array}{l}\text { Positive predictive } \\
\text { value }(\%)\end{array}$ & $\begin{array}{l}\text { Negative predictive } \\
\text { value (\%) }\end{array}$ \\
\hline 1. 이름을 부르는 말소리, 전화 벨소리, 사람 목소리 등에 반응합니까? & 20.0 & 100.0 & 100.0 & 40.7 \\
\hline 2. 혼자 있을 때도 재잘거리는 옹알이를 합니까? & 5.0 & 100.0 & 100.0 & 36.7 \\
\hline 3. 눈으로 소리가 나는 근원을 따라갈 수 있습니까? & 10.0 & 100.0 & 100.0 & 37.9 \\
\hline 4. 아기에게 말을 할 때 아기가 집중해서 듣습니까? & 20.0 & 100.0 & 100.0 & 40.7 \\
\hline 5. 말 같은 소리(/ㅂ/, /삐/, /ㅁ/으로 시작하는)를 가끔 내기도 합니까? & 25.0 & 90.9 & 83.3 & 40.0 \\
\hline 간단한 말소리를 따라하거나 흥내낼 수 있습니까? & 50.0 & 72.7 & 76.9 & 44.4 \\
\hline 보통 크기 소리로 좌, 우, 아래쪽 소리 방향을 구별할 수 있습니까? & 30.0 & 81.8 & 75.0 & 39.1 \\
\hline $\begin{array}{l}\text { 흔하게 사용하는 물건(우유병, 장난감)이나 } \\
\text { 말(‘안돼’, '안녕’ 등)을 알고 있습니까? }\end{array}$ & 35.0 & 72.7 & 70.0 & 38.1 \\
\hline $\begin{array}{l}\text { 출생 후 신생아 집중치료실(중환아실)에 } \\
\text { 5일 이상 입원한 적이 있습니까? }\end{array}$ & 20.0 & 63.6 & 50.0 & 30.4 \\
\hline 까꿍이나 짝짜꿍 놀이 등을 즐길 수 있습니까? & 5.0 & 81.8 & 33.3 & 32.1 \\
\hline 5개 문항의 조합 & 40.0 & 90.9 & 88.9 & 45.5 \\
\hline
\end{tabular}

Table 4. Analysis of the questions for the children aged 18-24 months

\begin{tabular}{|c|c|c|c|c|}
\hline Items & $\begin{array}{l}\text { Sensitiviy } \\
(\%)\end{array}$ & $\begin{array}{l}\text { Specificity } \\
(\%)\end{array}$ & $\begin{array}{l}\text { Positive predictive } \\
\text { value }(\%)\end{array}$ & $\begin{array}{l}\text { Negative predictive } \\
\text { value (\%) }\end{array}$ \\
\hline 1. 보통 크기의 소리로 모든 방향의 소리를 구별할 수 있습니까? & 33.3 & 100.0 & 100.0 & 60.0 \\
\hline $\begin{array}{l}\text { 2. “배고프니?”, “쉬 마려워?” 같은 단순한 예/아니오 식의 } \\
\text { 질문을 이해하고 반응합니까? }\end{array}$ & 26.7 & 93.3 & 80.0 & 56.0 \\
\hline 3. 자기의 이름(정확하지는 않더라도)을 말할 수 있습니까? & 66.7 & 73.3 & 71.4 & 68.8 \\
\hline 4. 책에 있는 그림을 말하면 맞는 그림을 가리킬 수 있습니까? & 46.7 & 80.0 & 70.0 & 60.0 \\
\hline $\begin{array}{l}\text { 5. 간단한 지시사항(“컵 주세요”, “공 가져와” 등)을 } \\
\text { 말로 듣고 이해합니까? }\end{array}$ & 26.7 & 86.7 & 66.7 & 54.2 \\
\hline 엄마, 아빠 외에 한 단어 이상 말할 수 있습니까? & 20.0 & 86.7 & 60.0 & 52.0 \\
\hline $\begin{array}{l}\text { 아기가 사용하는 단어에 다양한 자음(/ㅂ/,/삐/,/ㅁ/외// } \\
\text { ㄴ/,/ㄷ/,/匹/ 등)이 나타납니까? }\end{array}$ & 20.0 & 86.7 & 60.0 & 52.0 \\
\hline $\begin{array}{l}\text { 말을 듣고 익숙한 사물이나 신체부위(눈, 코, 입 등)를 } \\
\text { 가리킬 수 있습니까? }\end{array}$ & 26.7 & 80.0 & 57.1 & 52.2 \\
\hline $\begin{array}{l}\text { 간단한 이야기, 놀이(도리도리, 곤지곤지), } \\
\text { 노래(동요 포함) 등을 즐길 수 있습니까? }\end{array}$ & 6.7 & 93.3 & 50.0 & 50.0 \\
\hline $\begin{array}{l}\text { 출생 후 신생아 집중치료실(중환아실)에 } \\
\text { 5일 이상 입원한 적이 있습니까? }\end{array}$ & 20.0 & 80.0 & 50.0 & 50.0 \\
\hline 5개 문항의 조합 & 80.0 & 66.7 & 70.6 & 76.9 \\
\hline
\end{tabular}

Table 5. Analysis of the questions for the children aged 30-36 months

\begin{tabular}{|c|c|c|c|c|}
\hline Items & $\begin{array}{l}\text { Sensitiviy } \\
(\%)\end{array}$ & $\begin{array}{l}\text { Specificity } \\
(\%)\end{array}$ & $\begin{array}{l}\text { Positive predictive } \\
\text { value (\%) }\end{array}$ & $\begin{array}{l}\text { Negative predictive } \\
\text { value (\%) }\end{array}$ \\
\hline 1. 새로운 단어를 항상 배우고 있습니까? & 33.3 & 86.4 & 72.7 & 54.3 \\
\hline $\begin{array}{l}\text { 2. 두 어절을 이어서(“모두 주세요.”, “책 읽어줘.” 등) } \\
\text { 말할 수 있습니까? }\end{array}$ & 50.0 & 72.7 & 66.7 & 57.1 \\
\hline 3. TV 볼륨을 정상적인 크기로 시청합니까? & 20.8 & 85.7 & 62.5 & 48.6 \\
\hline 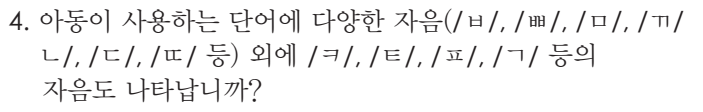 & 54.2 & 59.1 & 59.1 & 54.2 \\
\hline $\begin{array}{l}\text { 5. 반복되는 중이염(급성중이염을 } 6 \text { 개월간 } 4 \text { 회 이상, } \\
1 \text { 년간 } 6 \text { 회 이상 않은 경우)을 않은 적이 있습니까? }\end{array}$ & 29.2 & 77.3 & 58.3 & 50.0 \\
\hline 신생아기에 청각선별검사(청력검사)를 실시하였습니까? & 16.7 & 86.4 & 57.1 & 48.7 \\
\hline 주변의 사물 이름을 거의 알고 있습니까? & 37.5 & 68.2 & 56.3 & 50.0 \\
\hline 말로 지시한 내용을 대부분 이해하고 적절하게 행동합니까? & 20.8 & 81.8 & 55.6 & 48.6 \\
\hline 동요의 간단한 반복되는 후렴구나 리듬을 따라합니까? & 25.0 & 77.3 & 54.5 & 48.6 \\
\hline $\begin{array}{l}\text { “이게 뭐야?”, “이름이 뭐야?”, “엄마 어디에 있어?” 등의 } \\
\text { 간단한 질문에 답할 수 있습니까? }\end{array}$ & 37.5 & 63.6 & 52.9 & 48.3 \\
\hline 5개 문항의 조합 & 83.3 & 45.5 & 62.5 & 71.4 \\
\hline
\end{tabular}


Hearing Screening Questionnaire for Infants and Children I Lee J, et al.

Table 6. Analysis of the questions for the children aged $42-48$ months

\begin{tabular}{|c|c|c|c|c|}
\hline Items & $\begin{array}{c}\text { Sensitiviy } \\
(\%)\end{array}$ & $\begin{array}{l}\text { Specificity } \\
(\%)\end{array}$ & $\begin{array}{l}\text { Positive predictive } \\
\text { value }(\%)\end{array}$ & $\begin{array}{c}\text { Negative predictive } \\
\text { value }(\%)\end{array}$ \\
\hline $\begin{array}{l}\text { 1. 조용한 곳에서 아이 뒤로 한 팔 정도 떨어져, 아이 } \\
\text { 한쪽 귀를 번갈아 막고 속삭이듯 단어(연필, 학교 등)를 } \\
\text { 말하면, 양쪽 모두 정확하게 따라 말할 수 있습니까? }\end{array}$ & 45.5 & 95.0 & 83.3 & 76.0 \\
\hline 2. 아동이 하고자 하는 말을 대부분 이해할 수 있습니까? & 36.4 & 90.0 & 66.7 & 72.0 \\
\hline $\begin{array}{l}\text { 3. 출생 후 신생아 집중치료실(중환아실)에 } \\
\text { 5일 이상 입원한 적이 있습니까? }\end{array}$ & 45.5 & 85.0 & 62.5 & 73.9 \\
\hline 4. 아이가 같은 또래의 아이들만큼 말을 잘 합니까? & 63.6 & 75.0 & 58.3 & 78.9 \\
\hline 5. 대부분의 말소리를 정확히 발음할 수 있습니까? & 63.6 & 70.0 & 53.8 & 77.8 \\
\hline $\begin{array}{l}\text { 한문장에 세 개 내지 다섯 개 단어를 사용하여 } \\
\text { 말할 수 있습니까? }\end{array}$ & 9.1 & 95.0 & 50.0 & 65.5 \\
\hline 호기심이 많다고 생각할 정도로 질문이 많습니까? & 27.3 & 80.0 & 42.9 & 66.7 \\
\hline $\begin{array}{l}\text { 반복되는 중이염(급성중이염을 6개월간 4회 이상, } \\
1 \text { 1년간 6회 이상 않은 경우)을 않은 적이 있습니까? }\end{array}$ & 45.5 & 65.0 & 41.7 & 68.4 \\
\hline 더듬지 않고 부드럽게 말할 줄도 압니까? & 18.2 & 85.0 & 40.0 & 65.4 \\
\hline $\begin{array}{l}\text { 아이가 이전보다 소리에 대한 반응이 둔해지거나 } \\
\text { (뒤에서 불러도 돌아보지 않거나), TV 소리를 } \\
\text { 더 크게 하고 보는 경향이 있습니까? }\end{array}$ & 18.2 & 75.0 & 28.6 & 62.5 \\
\hline 5개 문항의 조합 & 81.8 & 60.0 & 52.9 & 85.7 \\
\hline
\end{tabular}

Table 7. Analysis of the questions for the children aged 54-60 months

\begin{tabular}{|c|c|c|c|c|}
\hline Items & $\begin{array}{l}\text { Sensitiviy } \\
(\%)\end{array}$ & $\begin{array}{l}\text { Specificity } \\
(\%)\end{array}$ & $\begin{array}{l}\text { Positive predictive } \\
\text { value (\%) }\end{array}$ & $\begin{array}{l}\text { Negative predictive } \\
\text { value }(\%)\end{array}$ \\
\hline 1. 간단한 동화나 이야기를 이해하고 그에 대한 질문에 답할 수 있습니까? & 33.3 & 100.0 & 100.0 & 78.9 \\
\hline 2. 간단한 문장 형태로 부드럽게 의사표현을 할 수 있습니까? & 33.3 & 100.0 & 100.0 & 78.9 \\
\hline $\begin{array}{l}\text { 3. 두 단계의 명령문(책을 집어서, 가방에 넣으세요)을 이해하고 } \\
\text { 수행할 수 있습니까? }\end{array}$ & 33.3 & 100.0 & 100.0 & 78.9 \\
\hline $\begin{array}{l}\text { 4. 어린이집, 놀이터, 친구 집 등에서 있었던 사건이나 } \\
\text { 놀이에 대하여 이야기할 수 있습니까? }\end{array}$ & 33.3 & 100.0 & 100.0 & 78.9 \\
\hline 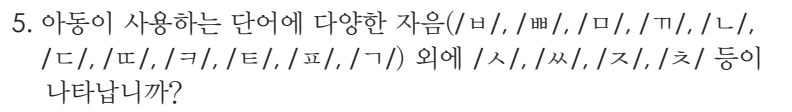 & 50.0 & 100.0 & 100.0 & 83.3 \\
\hline 전치사(위, 옆, 앞, 뒤)를 이해합니까? & 16.7 & 100.0 & 100.0 & 75.0 \\
\hline 신생아기에 청각선별검사(청력검사)를 실시하였습니까? & 16.7 & 93.3 & 50.0 & 73.7 \\
\hline 반복해서 말하지 않아도 잘 알아듣고 이해하여 행동합니까? & 33.3 & 80.0 & 40.0 & 75.0 \\
\hline 아이가 주의를 끌기 위해 큰 소리로 말하는 경우가 자주 있습니까? & 33.3 & 53.3 & 22.2 & 66.7 \\
\hline 글자와 숫자를 알기 시작하였습니까? & 0.0 & 100.0 & 0.0 & 71.4 \\
\hline 5개 문항의 조합 & 66.7 & 100.0 & 100.0 & 88.2 \\
\hline
\end{tabular}

\section{고 찰}

노인성 난청 환자를 비롯한 성인 난청 환자에서 청각장애에 대한 문진은 여러 연구자에 의해 주된 혹은 보조적인 선별 도 구로서 보고된 바 있다. ${ }^{17-22)}$ 유소아층에서 역시 문진으로서 난 청을 진단하고자 하는 시도가 여러 연구자에 의해 보고된 바 있다. ${ }^{23-30)}$ 그렇지만 성인 난청 환자와 달리, 많은 연구에서 유 소아층의 난청을 진단함에 있어 청각장애와 관련된 문진이 한 계가 있음을 언급하고 있다. ${ }^{26-30)}$ 난청의 진단에 있어, 문진을 선별의 도구로서 가치가 있음을 천명한 몇몇 논문 역시 응답
의 주체를 부모가 아닌 보모나 교사, 의료인력 등 전문지식을 갖춘 인력으로 한정하거나, 전문시설이 갖추어진 환경에서 적 용한다는 단서를 달아, 문진을 통한 난청의 진단을 보편화하 여 적용하는 근거로 삼기에는 부족하다. ${ }^{23-25)}$ 이는 유소아층의 경우 문진에 대한 응답이 환자 본인이 아닌 보호자에 의해 이 루어지며, 청각장애에 대한 반응이 비전형적이라는 점 등에서 이유를 유추해 볼 수 있다. 그렇지만 유소아층은 일반적인 청 력검사에 많은 제한점을 가지기 때문에, 난청의 조기 진단과 재활에 대한 필요성이 높아 타당성 있는 문진 항목의 개발은 여전히 임상적 유용성이 큰 주제이다. 
Table 8. Analysis of the questions for the children aged $66-71$ months

\begin{tabular}{|c|c|c|c|c|}
\hline Items & $\begin{array}{c}\text { Sensitiviy } \\
(\%)\end{array}$ & $\begin{array}{l}\text { Specificity } \\
(\%)\end{array}$ & $\begin{array}{l}\text { Positive predictive } \\
\text { value (\%) }\end{array}$ & $\begin{array}{l}\text { Negative predictive } \\
\text { value (\%) }\end{array}$ \\
\hline $\begin{array}{l}\text { 1. 일상적으로 사용하는 대부분의 모음과 자음을 } \\
\text { 맞게 발음할 수 있습니까? }\end{array}$ & 66.7 & 100.0 & 100.0 & 93.8 \\
\hline $\begin{array}{l}\text { 2. 조용한 곳에서 아이 뒤로 한 팔 정도 떨어져, } \\
\text { 아이 한쪽 귀를 번갈아 막고 속삭이듯 단어(연필,학교 등)를 } \\
\text { 말하면, 양쪽 모두 정확하게 따라 말할 수 있습니까? }\end{array}$ & 100.0 & 93.3 & 75.0 & 700.0 \\
\hline 3. 한 가지 주제에 대하여 이어서 이야기할 수 있습니까? & 66.7 & 93.3 & 66.7 & 93.3 \\
\hline 4. 어른이 하는 말을 정확히 따라할 수 있습니까? & 66.7 & 93.3 & 66.7 & 93.3 \\
\hline 5. 부모 또는 친척 중에 어려서부터 청각장애를 가진 사람이 있습니까? & 33.3 & 93.3 & 50.0 & 87.5 \\
\hline 작은 소리로 하는 말을 잘 이해합니까? & 100.0 & 73.3 & 42.9 & 100.0 \\
\hline $\begin{array}{c}\text { 아이가 이전보다 소리에 대한 반응이 둔해지거나(뒤에서 불러도 돌 } \\
\text { 아보지 않거나), TV 소리를 더 크게 하고 보는 경향이 있습니까? }\end{array}$ & 66.7 & 66.7 & 28.6 & 90.9 \\
\hline $\begin{array}{l}\text { 이전보다 말수가 줄어들거나 대화나 수업에 집중하지 } \\
\text { 못하고 산만합니까? }\end{array}$ & 33.3 & 80.0 & 25.0 & 85.7 \\
\hline $\begin{array}{l}\text { 반복되는 중이염(급성중이염을 6개월간 4회 이상, 1년간 6회 } \\
\text { 이상 앓은 경우)을 않은 적이 있습니까? }\end{array}$ & 66.7 & 46.7 & 20.0 & 87.5 \\
\hline 한 가지 주제에 대하여 이어서 이야기할 수 있습니까? & 0.0 & 93.3 & 0.0 & 82.4 \\
\hline 5 개 문항의 조합 & 100.0 & 80.0 & 50.0 & 100.0 \\
\hline
\end{tabular}

영유아 건강검진은 청각뿐 아니라 모든 신체발달을 신체 검 진 및 문진을 통해 검진하는 것으로 전체 건강검진을 위한 제 한된 시간과 신체검진으로 청각부분에 배당된 항목은 5 문항 이었다. 기존 문헌 고찰을 통해 이미 문항이 충분한 경우라도 순음청력검사를 대신할 수 없다는 것은 알려져 있으며, 문항 의 낮은 민감도와 특이도 때문에 청각 문진을 포기하는 경우 청각에 대한 최소한의 건강검진을 포기하는 것으로 5 문항 안 에서 최대한의 효과를 얻고자 하였다. 따라서 한 문장이라도 이상소견을 보이는 경우 양성으로 판단하여 민감도를 높이려 고 하였다. 기존 난청 선별을 위한 검사는 문항별 이상소견의 점수의 합을 이용하는 방식이나 현재 영유아 건강검진에서 사 용하는 방법은 한 문항이라도 이상소견을 보이는 경우 양성 으로 판정하고 있다. 이러한 문진의 특성상 민감도만이 높은 문항을 우선순위로 선별하는 경우 민감도는 더 이상 증가를 하지 않고 특이도, 양성예측률, 음성예측률 등의 변화는 없다. 하지만 양성예측률을 기준으로 한 경우에는 다른 특이도, 양 성예측률 등이 더 상승하기 때문에 적절한 민감도, 특이도, 음 성, 양성예측률을 유지하기 위해 본 연구에서는 모든 군에서 양성예측률이 높은 문항을 중심으로 문항을 선정하였다. 이 는 문항선별 기준이 최소 1 문항 이상 소견 시 의뢰로 되어 있 는 건강검진 문진의 구조상의 제한점으로 생각된다. 본 연구 에서 채택한 5 개의 문항을 조합했을 때 난청의 진단은 7 개 군 에서 평균적으로 $78.8 \%$ 의 민감도와 $68.7 \%$ 의 특이도를 보여, 11 문항이나 14 문항을 조합하여 난청의 진단을 시도한 이전의 연구와 대등한 진단율을 보였다. ${ }^{25,29)}$

연구 시작 전에 이미 문헌조사와 사전조사를 통해 문구를
작성하였으나 최종 문항선정과 정리는 자문회의를 통해 결정 하였다. 최종 문항선정 과정에서 금번 개정 작업을 통해 동시 에 개발 중이던 발달 장애 문항과의 중복성에 대한 검증을 실 시하였고, 설문조사 시 보호자가 어렵게 느끼거나 이해하기 어려운 문항을 개선하였다. 중이염은 영유아 시기 가장 흔한 질환이나 실제 조사결과 가장 효과적인 것으로 나온 연령 (30 36, 42 48, 66 71개월)에만 설문 항목으로 넣었다.

본 연구는 각 군별로 30 명 이상의 대상군을 확보하는 것을 목표로 하였다. 그렇지만 전향적 연구의 특성상 각 군의 대상 군이 고르게 모집되지 않았으며, 54개월 0일 60개월의 경우, 총 인원수가 21명 모집되었다. 54개월 0일 60개월 군과 66개 월 0일 71개월 군에서의 환아 비율도 정상군에 비해 적은 숫 자가 모집되어 통계적 의미를 산출함에 있어 한계가 있다. 이 는 추후 임상 영역에서의 지속적인 검증을 통해 보완되어야 할 것으로 보인다. 또한 대부분의 군에서 임상적으로 의미 있 는 민감도와 특이도를 보였지만, 민감도의 경우, 9 개월 0 일 12 개월 군에서 $40.0 \%, 54$ 개월 0일 60개월 군에서 $66.7 \%$ 를 보여 비교적 낮은 민감도를 나타냈으며, 특이도의 경우, 4개월 0 일 5 개월 군에서 $38.1 \%, 30 ~ 36$ 개월 군에서 $45.5 \%$ 를 보여, 특정 연 령대에서 난청의 진단에 있어 유효성이 떨어짐을 확인할 수 있 었다. 따라서 정확한 난청의 진단을 위해서는 해당 설문조사 에 의한 난청 선별보다는 청력검사에 의한 난청 선별이 필요 할 것으로 보인다. 따라서, 정규 교육이 시작되기 전인 만 5세 경에 1 회의 순음청력검사를 통한 청력검사가 시행되어야 할 것으로 보인다. 기존 문진을 전면 개정할 예정이어서 기존 문 진과 새 문진과의 비교 계획은 없었으며, 따라서 기존 문진과 
Table 9. Selected questions for the hearing screening

\begin{tabular}{|c|c|}
\hline Periods (months) & Selected Items \\
\hline $4-6$ & $\begin{array}{l}\text { - 큰 소리에 잠에서 깨거나, 놀라거나, 표정 변화 등으로 반응합니까? } \\
\text { - 익숙한 목소리를 들으면 조용해지거나 동작을 멈추고 듣는 것처럼 보입니까? } \\
\text { - 다양한 소리(끽끽거림, 껄껄거림, 높은 비명소리 등)를 낼 수 있습니까? } \\
\text { - 신생아기에 청각선별검사(청력검사)를 받았습니까? } \\
\text { - 위의 문항이 '예'인 경우 청력검사 결과가 양호(양측 통과 또는 이상 없음)라고 하였습니까? } \\
\text { (위 문항이 '아니오'인 경우 답하지 마세요) } \\
\text { - 출생 후 신생아 집중치료실(중환아실)에 5일 이상 입원한 적이 있습니까? }\end{array}$ \\
\hline $9-12$ & $\begin{array}{l}\text { - 이름을 부르는 소리, 전화 벨소리, 사람 목소리 등에 반응합니까? } \\
\text { - 혼자 있을 때도 재잘거리는 옹알이를 합니까? } \\
\text { - 소리가 나는 곳을 눈으로 따라가며 봅니까? } \\
\text { - 아이에게 말을 할 때 아이가 집중해서 듣습니까? } \\
\text { - ㅂ, 뽀, 므으로 시작하는 말하는 듯한 소리를 가끔 내기도 합니까? }\end{array}$ \\
\hline $18-24$ & $\begin{array}{l}\text { - 모든 방향에서 나는 보통 크기의 소리를 구별할 수 있습니까? } \\
\text { - “배고프니?", “쉬 마려워?” 같은 단순한 예/아니오 식의 질문을 이해하고 반응합니까? } \\
\text { - 자기의 이름(정확하지는 않더라도)을 말할 수 있습니까? } \\
\text { - 책에 있는 그림을 말하면 맞는 그림을 가리킬 수 있습니까? } \\
\text { - 간단한 지시사항(컵 주세요, 공 가져와 등)을 말로 듣고 이해합니까? }\end{array}$ \\
\hline $30-36$ & $\begin{array}{l}\text { - 아이가 말하는 단어의 개수가 지속적으로 늘어나고 있습니까? } \\
\text { - 두 어절을 이어서 말할 수 있습니까? “모두 주세요.", “책 읽어줘." 등) } \\
\text { - TV 소리를 다른 사람보다 크게 높입니까? } \\
\text { - 아이가 ㅋ, ㅌ, 표, ㄱ등의 자음이 포함된 단어를 사용할 수 있습니까? } \\
\text { - 급성 중이염을 여러 번 않은 적이 있습니까?(6개월간 4회 이상, 1년간 6회 이상) }\end{array}$ \\
\hline $42-48$ & $\begin{array}{l}\text { - 조용한 곳에서 아이 뒤로 한 팔 거리 정도 떨어져, 아이 한쪽 귀를 막고 속삭이듯 말하는 단어(연필, 학교 등)를 } \\
\text { 양쪽 모두 정확하게 따라 할 수 있습니까? } \\
\text { - 아이가 하는 말을 대부분 이해할 수 있습니까? } \\
\text { - 출생 후 신생아 집중치료실(중환아실)에 5일 이상 입원한 적이 있습니까? } \\
\text { - 아이의 발음이 정확합니까? } \\
\text { - 아이가 같은 또래의 아이들만큼 말을 잘 합니까? }\end{array}$ \\
\hline $54-60$ & $\begin{array}{l}\text { - 간단한 동화나 이야기를 듣고 질문에 답할 수 있습니까? } \\
\text { - 간단한 문장으로 자연스럽게 의사표현을 할 수 있습니까? } \\
\text { - 두 단계의 명령문을 이해하고 수행할 수 있습니까(책을 집어서, 가방에 넣으세요)? } \\
\text { - 어린이집, 놀이터, 친구 집 등에서 있었던 일들을 이야기 할 수 있습니까? } \\
\text { - 아이가 ㅅ, ㅆ, ㅈ, ㅊ 등의 자음이 포함된 단어를 사용할 수 있습니까? } \\
\text { - 전치사(위, 옆, 앞, 뒤)를 이해합니까? }\end{array}$ \\
\hline $66-71$ & $\begin{array}{l}\text { - 대부분의 모음과 자음을 맞게 발음할 수 있습니까? } \\
\text { - 작은 소리로 하는 말을 잘 이해합니까? } \\
\text { - 다른 사람들과 쉽게 말로 대화할 수 있습니까? } \\
\text { - 어른이 하는 말을 정확히 따라할 수 있습니까? } \\
\text { - 부모 또는 친척 중에 어려서부터 청각장애를 가진 사람이 있습니까? }\end{array}$ \\
\hline
\end{tabular}

의 민감도 특이도와의 차이를 분석할 수는 없었다.

\section{Acknowledgments}

This study was supported by Revision of the Manual of the National Health Screening Program for Infants \& Children with Development of Education Materials for Medical Doctors.

\section{자문 위원단}

청각 연구원

서울대학교 박무균 교수

한림대학교 박수경 교수
청각 자문위원

가톨릭대학교 박경호 교수

서울대학교 이준호 교수

전남대학교 조형호 교수

한림대학교 김진숙 교수

한림대학교 장지원 교수

소아과 참여 연구원

관동대학교 제일병원 신손문 교수

국립의료원 신혜정 교수 


\section{REFERENCES}

1) Bamford J, Fortnum H, Bristow K, Smith J, Vamvakas G, Davies L, et al. Current practice, accuracy, effectiveness and cost-effectiveness of the school entry hearing screen. Health Technol Assess 2007;11 (32):1-168, iii-iv.

2) American Academy of Pediatrics, Joint Committee on Infant Hearing. Year 2007 position statement: Principles and guidelines for early hearing detection and intervention programs. Pediatrics 2007;120 (4):898-921.

3) Kim SH, Byun YC, Son CK, Lee YH, Lee MK, Lee SH, et al. A year research on the actual condition of the disabled. Sejong: Ministry of Health \& Welfare, Korea Institute for Health and Social Affairs; 2011.

4) National Institute on Deafness and Other Communication Disorders (NIH). Your Baby's Hearing and Communicative Development Checklist [cited 2014 Aug 8]. Available from: URL: http://www.nidcd. nih.gov/health/hearing/pages/silence.aspx.

5) DHHR. NHS Check List [cited 2014 Aug 8]. Available from: URL: http://www.wvdhhr.org/nhs/nhs-checklist.asp.

6) Your Baby's Hearing Checklist [cited 2014 Aug 8]. Available from: URL: http://phpa.dhmh.maryland.gov/genetics/docs/brochure why_a_hearing_screening.pdf.

7) Your Baby's Hearing Checklist [cited 2014 Aug 8]. Available from: URL: http://phpa.dhmh.maryland.gov/genetics/docs/Infant Hearing/BabyBabyDoYouHearMe.82004.pdf.

8) NHS Wales. Checklist for Parents [cited 2014 Aug 8]. Available from: URL: http://www.wales.nhs.uk/sitesplus/980/page/55652.

9) TEXAS. TEHDI - Hearing Checklist [cited 2014 Aug 8]. Available from: URL: https://www.dshs.state.tx.us/tehdi/Audiology-ServicesHearing-Checklist.aspx.

10) Texas Children's Hospital. Audiology [cited 2014 Aug 8]. Available from: URL: http://www.texaschildrens.org/departments/audiology/ speech-and-hearing-checklist.

11) PEDIATRIX MEDICAL GROUP. Milestones Checklisk [cited 2014 Aug 8]. Available from: URL: http://www.pediatrix.com/body hs.cfm?id=4425.

12) Kim KS, Kim JS, Kim HJ, Bang JH, Lee KW, Lee JH, et al. Introduction to audiology. Seoul: Hakjisa;2014. p.299-329.

13) Kim JS, Ji YS, Shin HO. A study of infant's vocal production patterns for developing early aural rehabilitation program. Audiology 2012;8(1):61-77.

14) Shim HS, Kim YT, Kim JS, Kim HH, Kim SY, Shin MJ, et al. Understanding of communication disorder. Seoul: Hakjisa;2010.

15) Northern JL, Downs MP. Hearing in children. 6th ed. San Diego: Plural Publishing, Inc.;2014.
16) Seewald R, Tharpe AM. Comprehensive Handbook of Pediatric Audiology. 1st ed. San Diego: Plural Publishing, Inc.;2010.

17) Diao M, Sun J, Jiang T, Tian F, Jia Z, Liu Y, et al. Comparison between self-reported hearing and measured hearing thresholds of the elderly in China. Ear Hear 2014;35(5):e228-32.

18) Swanepoel de W, Eikelboom RH, Hunter ML, Friedland PL, Atlas MD. Self-reported hearing loss in baby boomers from the Busselton Healthy Ageing Study: audiometric correspondence and predictive value. J Am Acad Audiol 2013;24(6):514-21; quiz 529.

19) Deepthi R, Kasthuri A. Validation of the use of self-reported hearing loss and the Hearing Handicap Inventory for elderly among rural Indian elderly population. Arch Gerontol Geriatr 2012;55(3):762-7.

20) Ramkissoon I, Cole M. Self-reported hearing difficulty versus audiometric screening in younger and older smokers and nonsmokers. J Clin Med Res 2011;3(4):183-90.

21) Hannula S, Bloigu R, Majamaa K, Sorri M, Mäki-Torkko E. Selfreported hearing problems among older adults: prevalence and comparison to measured hearing impairment. J Am Acad Audiol 2011;22(8):550-9.

22) Ferrite S, Santana VS, Marshall SW. Validity of self-reported hearing loss in adults: performance of three single questions. Rev Saude Publica 2011;45(5):824-30.

23) Newton VE, Macharia I, Mugwe P, Ototo B, Kan SW. Evaluation of the use of a questionnaire to detect hearing loss in Kenyan preschool children. Int J Pediatr Otorhinolaryngol 2001;57(3):229-34.

24) Olusanya B. Early detection of hearing impairment in a developing country: what options? Audiology 2001;40(3):141-7.

25) Samelli AG, Rabelo CM, Vespasiano AP. Development and analysis of a low-cost screening tool to identify and classify hearing loss in children: a proposal for developing countries. Clinics (Sao Paulo) 2011;66(11):1943-8.

26) Hammond PD, Gold MS, Wigg NR, Volkmer RE. Preschool hearing screening: evaluation of a parental questionnaire. J Paediatr Child Health 1997;33(6):528-30.

27) Gomes M, Lichtig I. Evaluation of the use of a questionnaire by nonspecialists to detect hearing loss in preschool Brazilian children. Int J Rehabil Res 2005;28(2):171-4.

28) $\mathrm{Bu} \mathrm{X,} \mathrm{Li} \mathrm{X,} \mathrm{Driscoll} \mathrm{C.} \mathrm{The} \mathrm{Chinese} \mathrm{Hearing} \mathrm{Questionnaire} \mathrm{for} \mathrm{school}$ children. J Am Acad Audiol 2005;16(9):687-97.

29) Li X, Driscoll C, Culbert N. Investigating the performance of a questionnaire for hearing screening of schoolchildren in China. Aust N Z J Audiol 2009;31(1):45-52.

30) Alvarenga Kde F, Araújo ES, Melo TM, Martinez MA, Bevilacqua MC. Questionnaire for monitoring auditory and language development in the first year. Codas 2013;25(1):16-21. 